\title{
Characterization and Comparison of Microbial Soil Diversity in Two Andean Peatlands in Different States of Conservation-Vega Tocorpuri
}

\author{
Carolina Belfiore1, Ana Fernandez ${ }^{1}$, Ana Paula Santos ${ }^{1}$, Manuel Contreras ${ }^{2}$, \\ María Eugenia Farías ${ }^{*}$ \\ ${ }^{1}$ Laboratorio de Investigaciones Microbiológicas de Lagunas Andinas (LIMLA), Planta Piloto de Procesos Industriales \\ Microbiológicos (PROIMI-CONICET), Tucumán, Argentina \\ ${ }^{2}$ Centro de Ecología Aplicada (CEA), Suecia, Chile \\ Email: *mefarias2009@gmail.com
}

How to cite this paper: Belfiore, C., Fernandez, A., Santos, A.P., Contreras, M. and Farías, M.E. (2018) Characterization and Comparison of Microbial Soil Diversity in Two Andean Peatlands in Different States of Conservation-Vega Tocorpuri. Journal of Geoscience and Environment Protection, 6, 194-210.

https://doi.org/10.4236/gep.2018.64012

Received: December 13, 2017

Accepted: April 8, 2018

Published: April 11, 2018

Copyright ( 2018 by authors and Scientific Research Publishing Inc. This work is licensed under the Creative Commons Attribution International License (CC BY 4.0).

http://creativecommons.org/licenses/by/4.0/

\section{c) (i) Open Access}

\begin{abstract}
Cerro Tocorpuri, belongs to the II region of Chile, in San Pedro de Atacama, on the border of Chile-Bolivia. The presence of a more or less constant supply of water conditions the existence of characteristic vegetation systems known as bogs (bofedales, vegas and marshes). These wetlands have a cultural, environmental and economic social importance. As a result of the exploitation of aquatic rights, peatlands began to dry up with the consequent loss of natural resources and damage to ancestral rights, and natural resources. The activities of microorganisms in wetlands play an important role in biogeochemical processes. The interaction between microbial diversity and soil, influences to the ability of the ecosystem to recover from stress (resilience). In the present work, the soil characteristics and the associated microbial biodiversity were studied, comparing samples of active and deteriorated peatland. It was seen that the loss of water causes great changes in the physical-chemical characteristics of the soil, which leads to a modification of the microbiota Proteobacteria decreased by $18 \%$ in deteriorated peatlands, which are evident more sensible to extreme conditions while Acidobacteria, Actinobacteria increased in these sample showing a better adaptation to the change of conditions. In view of the fact that high Andean Peatlands are exposed to increasing environmental impact, this preliminary comparative study of pristine and altered soil could guide the research directed to recovery of dead peatlands strategies.
\end{abstract}

\section{Keywords}

Peatland, Microbial Diversity, Altered Soil 


\section{Introduction}

The Atacama Desert is the driest and oldest desert on Earth. Its surface conditions have remained relatively unchanged for millions of years [1] [2]. It has more than 100 basins with interior drainage, and most of them contain salt flats. These ecosystems are characterized by extreme aridity, strong winds, scarce but torrential rainfall, high rates of evaporation, high solar radiation, extreme daily temperature changes, negative water balance, combined with a wide range of salinity [1] [3] [4]. The salt composition is dominated by sulfate, chloride, sodium, and divalent cations [3] [5]. In spite of all of this, phototrophic and heterotrophic bacteria have recently been found in halite and gypsum evaporites and microbial mats [5] [6].

Cerro Tocorpuri, which belongs to the II region of Chile, is located at $5200 \mathrm{~m}$ a.s.l., in San Pedro de Atacama, on the border of Chile-Bolivia. Its coordinates are $22^{\circ} 25^{\prime} 60^{\prime \prime S}$ and $67^{\circ} 55^{\prime} 0^{\prime \prime} \mathrm{W}$ in DMS (Degrees Minutes Seconds).

In regions I and II of Chile, the presence of a more or less constant supply of water, conditions the existence of typical vegetation systems known as peatland (bofedales, vegas and bogs), which technically belong to a humid environment [7]. Peatlands are plant formations that are established in an edaphic environment, mainly organic, characterized by a permanent saturated water condition, presenting a great biological diversity and a greater number of vegetal species with respect to the environment, which are characteristic of these systems. These wetlands are areas of valuable forage and watering hole threatened species conservation as vicuña, guanaco, llama, alpaca among others [7]. They are unique ecosystems, with a high vulnerability; the water is a fundamental factor that makes the development of the Andean biota possible in this high desert [8] (http://www.conaf.cl/humedales-chilenos-altoandinos-ecosistemas-estrategicosde-importancia-internacional/).

The vegetation types correspond to biological ecological systems azonal, with characteristic vegetation due to the high and permanent soil moisture content [7] [9]. These wetlands have cultural, environmental and economic social importance, since it is the livelihood for communities [7].

The microbial processes in wetland are regulated for the hydrology [10] [11] [12] [13] [14]. Peatland began to dry up with the consequent loss of natural resources (flora and fauna) and the damages to the natural resources ancestral rights (including water) of indigenous communities, due to the acquisition and exploitation, the water rights by other non-agricultural uses (mainly mining) that are risking the sustainability and survival of these groups [7] [10].

It is known that the soil is a complex habitat with a large number of microbial populations [15]. The microbial diversity in soil ecosystems exceeds, by far, that of the eukaryotic organisms. Less than $1 \%$ of the billion microorganisms of the soil can be cultivated and characterized, soil ecosystems are, general, uncharted [16]. The activities of microorganisms in wetlands play an important role in biogeochemical processes and they are key to the functions of wetland [5] [17]. 
So it is necessary to know the microbial diversity to exploit the potential of the wetland ecosystems [18].

Although the interaction between the biodiversity and its function in the soil is not well studied, it is thought that has a positive influence on stability, productivity and resilience towards stress and disturbance [17]. They are responsible of regulating the dynamics of soil organic matter, carbon sequestration and emission of greenhouse gases. On the other hand, they modify the physical structure of the soil, enhancing the amount and efficiency nutrient acquisition for health of plants. Thereby, there is a conflict between industrial development and the protection of these natural resources [19]. Soil bacteria communities regulate wetland biogeochemical processes, however, there is little knowledge about their distribution and abundance [23].

Peatland degradation was associated with the changes occurred in the regional precipitation, the high water demand for lowland agriculture, urbanization and mining, all of them exceeding the availability of water [7] [10] [20] [21] [22]. In Atacama region water extraction for miner projects have increase in the last decades affecting peatlands. Their recovery is not a matter of water or vegetation restitution, since those strategies have failed, so the study of the microbiota is interesting.

The objective of this work was to study the soil characteristics and microbial biodiversity of soils associated to rhizosphere of wetlands, comparing a "deteriorated peatland (dead peatland)" with a "peatland in good condition (active peatland)". The results would able to determine which are the essential biotic components in the rhizosphere in order to implement a recovery technology.

\section{Material and Methods}

\subsection{Sample Sites and Sampling}

Samples were taken in July 2015, from Tocorpuri Peatland, a place located in Second Region, Antofagasta, Chile.

Soils samples in different stages of preservation were collected, deteriorated soil (dead peatland) and soil in good condition (active peatland), as shown in Figure 1(a) and Figure 1(b) respectively.

\subsection{DNA Extraction, PCR and Pyrosequencing}

Total genomic DNA was isolated using the Power Biofilm DNA Isolation Kit (MO BIO Laboratories, inc.) according to the supplied protocol. Extracted DNA samples were amplified with F357 and R926 primers (NIH HMP Working Group, 2009). The reactions were performing according [81]. All sequences of the pyrosequencing runs were deposited in the NCBI Sequence Read Archive (SRA) database under the following accession number SRP120032.

\subsection{Chemical Analysis and Moisture Content}

The determination of organic material (OM), C (\%), Nitrates (\%), P (ppm), S 


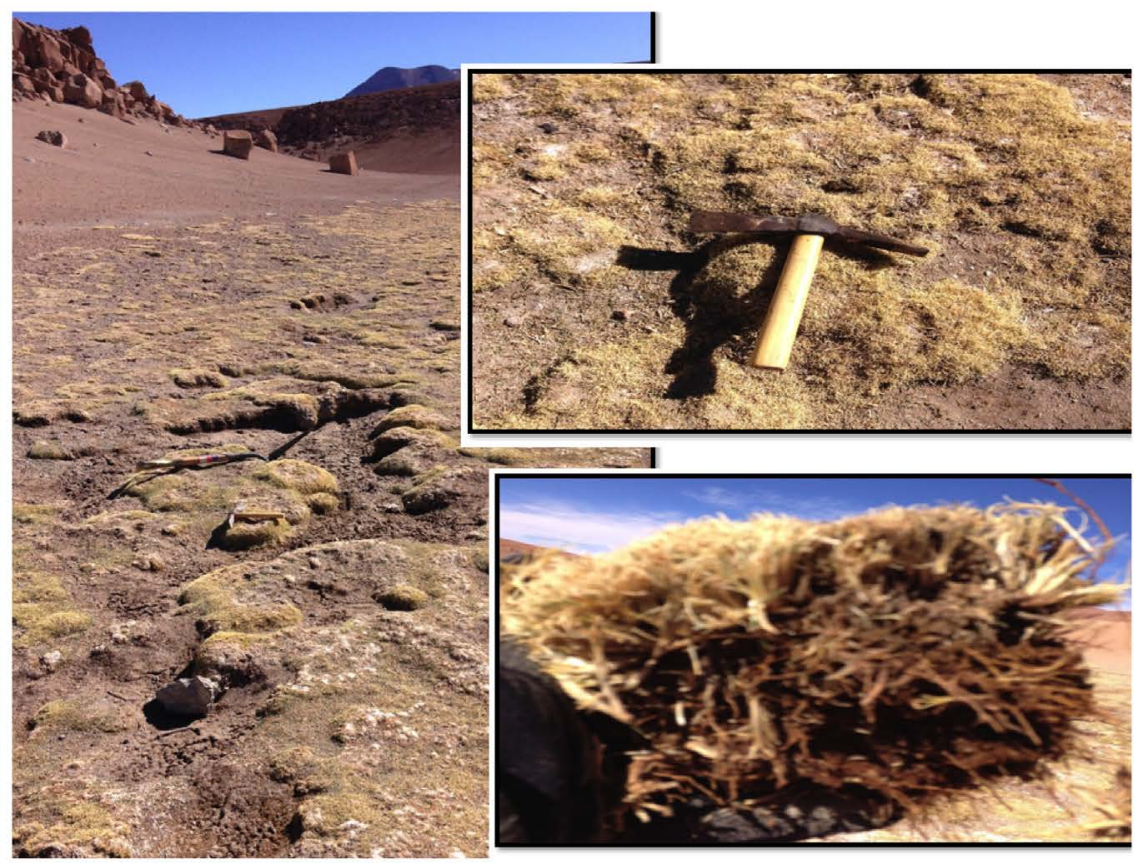

(a)

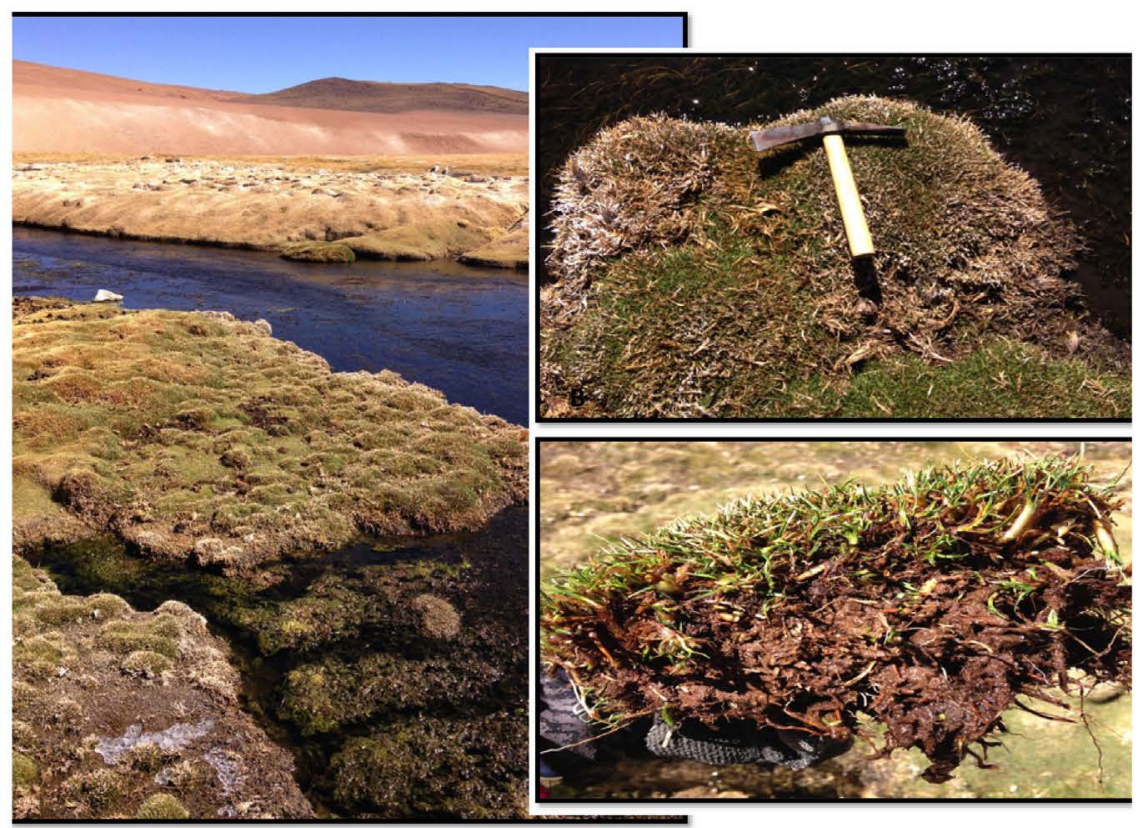

(b)

Figure 1. Photographs of peatland in different state of preserving: (a) dead and (b) active peatland.

(\%) was carried out by standard methods in pH7 diagnóstico agrícola.

To calculate the $\%$ moisture for each sample, $10 \mathrm{~g}$ of the material was weighed into petri plate (pre-weighed), and the sample was dried for $24 \mathrm{hs}$ in a $100^{\circ} \mathrm{C}$ oven (to constant weight). The moisture content was calculated using the following equation: 


$$
\mathrm{W}=[(\mathrm{PP}+\mathrm{wS})-(\mathrm{PP}+\mathrm{DS}) /(\mathrm{PP}+\mathrm{DS})-\mathrm{PP}] * 100
$$

W: \% moisture; PP: Petri Plate; wS: wet Sample; DS: Dry sample.

\subsection{Scanning Electron Microscopy}

The samples processed as described by [80] was observed in Zeiss Supra 55vp (Carl ZeissNTS GmbH, Germany) scanning microscopy in the Centro Integral de Microscopía Electrónica (CIME-CONICET-UNT).

\subsection{Microbial Analysis}

Ten grams of active and dead peatland samples were suspended in $90 \mathrm{ml}$ of peptone water (bacteriological peptone, $0.1 \%$ ) and vortexed thoroughly for $10 \mathrm{~min}$. From these stock solutions, serial dilutions were performed and plated in duplicated on each culture media: total counts on Agar nutritive incubated for $48 \mathrm{~h}$ at $30^{\circ} \mathrm{C}$. On the other hand, BG11 medium [24] was used to culture cyanobacteria, the Erlenmeyer flasks were incubated under Light: Dark cylces $(16: 8 \mathrm{~h})$ at $28^{\circ} \mathrm{C} \pm 1^{\circ} \mathrm{C}$ during 14 days. The algal specimens will be observed under binocular microscopes Leitz SM Lux and Zeiss Axio 1. Determination to gene level will be based on [25].

\section{Results and Discussion}

Many times result difficult to separate soil functions into chemical, physical, and biological processes due of the dynamic nature of these processes. Chemical properties of numerous soil directly influence microbiological processes, and these, together with physical-chemical processes determine, the capacity to hold, supply, and cycle nutrients and on the other hand, the movement and availability of water [26].

Comparative physical chemical analysis between both samples showed a clear evidence of a higher percentage of moisture present in active peatland (92\%) compared with dead peatland (47\%). Soil pH is an important factor that affects directly the availability of nutrients and the chemical characteristics of the environment. The microorganisms have optimal $\mathrm{pH}$ ranges for their growth, when altered in the environment; significantly modify microbial density [27]. Soil pH levels near 7 are optimal for overall nutrient availability and crop tolerance [28]. On the other hand, the most of microorganisms grow better in mineral soils with neutral $\mathrm{pH}$ values, and they significantly reduce their activity when the $\mathrm{pH}$ is below 5.5 or above 9.0 [29]. In our studies to the $\mathrm{pH}$ in active peatland, the values were slightly alkalic (7.8) while in dead peatland they were strongly alkaline (9.1). The causes of change in $\mathrm{pH}$ are not clear but, probably the decrease of the vegetation in the dead peatland is influencing the increase of the $\mathrm{pH}$ since it is known that the Cation exchange may be the most important mechanism for the generation of acidity in peatlands. There is a direct relationship between $\mathrm{pH}$ and the exchangeable metabolic activity of the plants [30].

The conductivity measurements show that in active and dead peatland, they 
have low conductivity values $(0.25 \mathrm{dS} / \mathrm{m}$ and $0.28 \mathrm{dS} / \mathrm{m}$ respectively). The electrical conductivity was used to classify the samples as slightly saline soils because the values obtained in both cases were among $0-0.2 \mathrm{dS} / \mathrm{m}$. As shown in Table 1 all physical parameters were higher in active sample. Soil organic matter (OM) is a key indicator of soil quality, intervenes in multiple functions in the soil, such as the ability to include nutrient retention, water holding capacity, and soil aggregation [28] [31]. This value is higher in the conserved peatland. With regard to the content of $\mathrm{S}, \mathrm{P}$ and $\mathrm{N}-\mathrm{NO}_{3}$ as shown in Table 1, are higher in the active sample. In general, in soils with $\mathrm{pH} 6.5$ to 8 , these nutrients would be more available [28], therefore, in active peatland, they are more readily available than dead peatland where the $\mathrm{pH}$ value was higher.

Nitrogen is an important, growth-limiting nutrient in many peatlands [32] [33]; it can be added to the peat surface through atmospheric deposition or fixed by microbes [34] [35]. Our result showed that $\mathrm{N}-\mathrm{NO}_{3}$ content in active sample is significantly higher than in dead peatland. Moreover, sulfur plays an important role in the oxidation-reduction biogeochemistry of peatlands, influencing the production and emission of methane to the atmosphere [36] [37] [38] [39] and the mineralization of C [39] [40]. It can be supplied to peatlands by groundwater or like nitrogen through atmospheric deposition [41]. Peat $S$ concentrations range greatly from 10 to $100 \mathrm{ppm}$ in a Minnesota bog [42], to $800-7000 \mathrm{ppm}$ in peatlands in West Virginia, Czechoslovakia and Alberta [40] [43] [44]. In our work, values of $502 \mathrm{ppm}$ were obtained in the active peat, values that are higher than that found in the dead sample (102 ppm).

The microbiological state of the soil is a critical element in the studies of microbial ecology. The total viable counts on agar nutritive showed differences between analyzed samples. The number of cultivable microorganisms was higher in active peatland $8.89 \pm 0.18 \log \mathrm{CFU} \mathrm{m}{ }^{-1}$ compared with $6.85 \pm 0.3 \log \mathrm{CFU}$ $\mathrm{ml}^{-1}$ in dead peatland.

The soil is considered ecologically habitat extremely stable [45]. The number and types of microorganisms present in a soil depend on various environmental factors such as nutrients, moisture, aeration, temperature, $\mathrm{pH}$, agricultural practices, etc. [46]. Some microorganisms of a habitat may be dominant. The populations and the structure of the community tend to be kept constant, however, this homeostasis and dominance of certain populations can be disrupted when

Table 1. Analysis of soil samples.

\begin{tabular}{ccc}
\hline & Dead peatland & Active peatland \\
\hline Organic material (\%) & 3.78 & 29.18 \\
$\mathrm{C}(\%)$ & 1.89 & 14.59 \\
$\mathrm{~N}-\mathrm{NO}_{3}$ total (\%) & 24.30 & 260 \\
$\mathrm{P}(\mathrm{ppm})$ & 17.80 & 21.10 \\
$\mathrm{~S}(\mathrm{ppm})$ & 150 & 502 \\
\hline
\end{tabular}


environmental conditions are altered. In the case of "dead peatland" samples, water is the main factor that affects the structure of microbial communities, affected mainly by human activity. To elucidate differences in microbial community structure between wet and dry soils, pyrosequencing was undertaken. The results obtained reveal that the most of the $16 \mathrm{~S}$ rRNA gene sequences were affiliated with Proteobacteria, Actinobacteria and Acidobacteria in both samples, and they were the most responsive phyla to change in study samples. As shown in Figure 2, Proteobacteria decreses in dead peatland while Actinobacteria, Acidobacteria and Gematimoidetes increases in dead peatland. Bacteroidetes, Firmicutes, Chloroflexi, Chlorobi, Latescibacteria, Cyanobacteria and Nistrospirae were found in the same proportion in all samples.

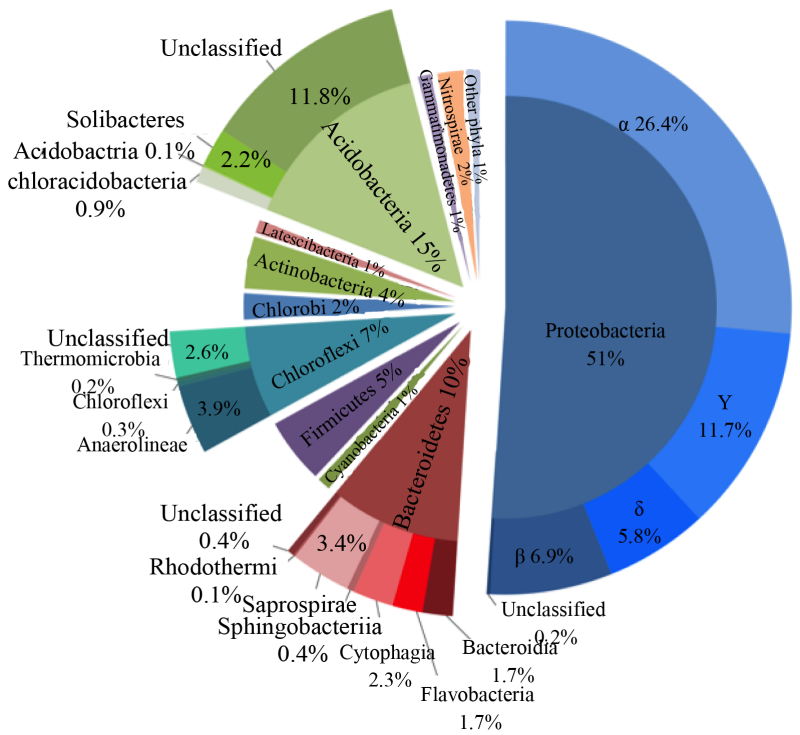

(a)

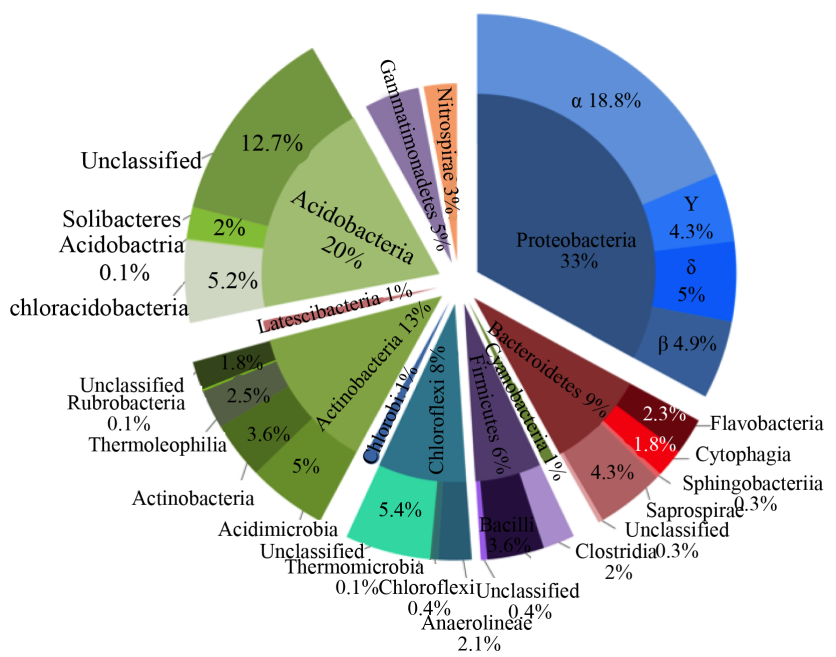

(b)

Figure 2. Comparison of the microbial diversity associated with active (a) and dead (b) peatland. 
Regarding proteobacteria phylum there is a decrease of the $18 \%$ in dead soils, comparing with active soils. The classes Alpha, Gamma, Beta and Delta are in all samples; however abundance in each sample was different. In dead soils there is a decrease of the percentage (33\%) comparing with proteobacteria present in active soils (51\%). The Alphaproteobacteria were more abundant $26 \%$ and $18.8 \%$ in active and dead sample respectively, while Gammaproteobacteria in active peatland was $7 \%$ higher that their presence in dead peatland. These results are in concordance to that published by [47]; who reported that Proteobacteria, mainly Gammaproteobacteria, decreased in abundance with desiccation in Chinese and Japanese soils.

The Actinobacteria are a group of bacteria with a highly active secondary metabolism, they are found in large amounts in the peat layers, decomposing cellulose and other plant polymers [48]. They are important in the decomposing and degrading of mixture of organic polymers and plays and interesting role to the recycling nutrients associated with recalcitrant polymers [49] [50] [51]. An advantage over Gram-negative soil bacteria is their ability to spread through relatively dry soil and to survive in adverse conditions [52]. Previous studies have demonstrated that this phylum was drought resistant and able to grow under extreme dry conditions [53] [54]. Our results shown, that Actinobacteria increased in relative abundance with desiccation. This results is agrees with the response of bacterial communities in California grassland soil study [55] and the results obtained by [47] [56] who shown that this phylum were one of the most responsive to change in water availability; increased with dry-down and decreased with wet-up.

One of the most abundantly distributed bacterial groups in the environment corresponds to Acidobacteria [57] [58] [59]. Its members have been detected in numerous $16 \mathrm{~S}$ rRNA gene surveys from different environments as soil, sediment, fresh-water, marine and extreme environments [57] [58] [60]. It is known that access to nutrients becomes more limited when the water film thickness is reduced by drought [61]. Bacteria have strategies to surviving desiccation [62] [63], for example recently it was seen that Acidobacteria produces exopolysacchaides. Our results showed that Acidobacteria increased 5\% in dry peatlands, which shows the resistance of this group to environmental conditions.

DeBruyn [64] observed that the highest proportions of Gemmatimonadetes were found in arid soils, suggesting an adaption to low-moisture environments, which explains the higher percentage of these phyla, found in the dead samples.

With regard the phylum Bacteroidetes, have colonized virtually all types of habitats on Earth [65]. They are frequent members of microbial mats, due to their ability to degrade organic compounds [66]. Their presence is similar in wetter soil (10\%) compared to dry soil (9\%). About Choloflexi, this group has not been previously associated with arid soil communities [67]. A recent study, that evaluated growth rates of soil bacteria found that Chloroflexi is a slow-growing bacteria [68]; this type of bacteria typically have a good tolerance to drought 
[69], which would explain its presence in dead peatland samples.It is known that Firmicutes produce endospores under stressful environmental conditions [70], this group appear en both samples in the same proportions, as well as Nitrospirae that was found in equal proportions in both samples.

Latescibacteria with cyanobactyeria are present in low proportions (1\%). Latescibacteria, little is known about this phylum; however Youssef et al., 2015 suggest that latescibacteria transform algal detritus sinking from sunlit surface waters into fermentation products to contribute to microbial food webs in waters bellow. On the other hand some members of Letescibacteria may be capable of forming greigite magnetosomes, and play unrecognized roles in iron and sulfur cycles [71].

Although, cyanobacteria dominated the bacterial populations of many extreme environments [72], and many studies reveal the ability of this phylum to withstand large periods of drying [62] [73] [74] [75] [76] [77]. Nevertheless the scarcity of cyanobacteria in the present work is in accordance to the observations of a low cyanobacterial presence from the Salar de Atacama [5] [78] [79] [80] [81].

From the active peatland samples, it was possible to isolate different genera of cyanobacteria (Figure 2), and they could be observed under a microscope as shown Figure 3(A). However, in the samples from the dead peatland, they were absent. Our results are in accordance with [82], who reported a low or absent cyanobacterial signatures in arid soils of the McKelvey Valley, and on the other hand with the molecular-based studies by [83] [84] [85] [86], inform that cyanobacteria are being absent at all arid studies sites. Electron microscopy revealed a clear difference between active and dead samples (Figure 3). It can be observed strong association between roots and Cyanobacteria (Figure 3(A)) with the presence of diatoms (Figure 3(C)), and Prokaryotes (Figure 3(B)). On the other hand, in the dead sample, inorganic remains were observed and there were no roots as in the active sample (Figure $3(\mathrm{D})$ ).

Diatoms and cyanobacteria were isolated from preserved peatland using BG11 medium. Four type of cyanobacteria were identified: Oscillatoria sp.; Lyngbya sp.; Nostoc sp. and Dolichospermum sp. and with regard diatoms five type grew: Ulnaria sp.; Cocconeis placentula; Pinnularia sp.; Nitzschia sp., and Rhopalodia sp. (Figure 4).

It is known that the diatoms respond quickly to any subtle changes in the environmental conditions and hence they are the most promising tools in biomonitoring [87] [88]. Diatoms are the only unicellular partners to form associations with heterocyst forming cyanobacteria [89]. Heterocysts are specialized nitrogen fixing cells present in some filamentous cyanobacteria, such Nostoc, Cylindrospermun, Anabaena and Dolichospermun. Some of them are present in the samples studies.

This work began the studies of soils associated with peatland in different states of preservation. Although this is only a first approach to the microbial ecology of 


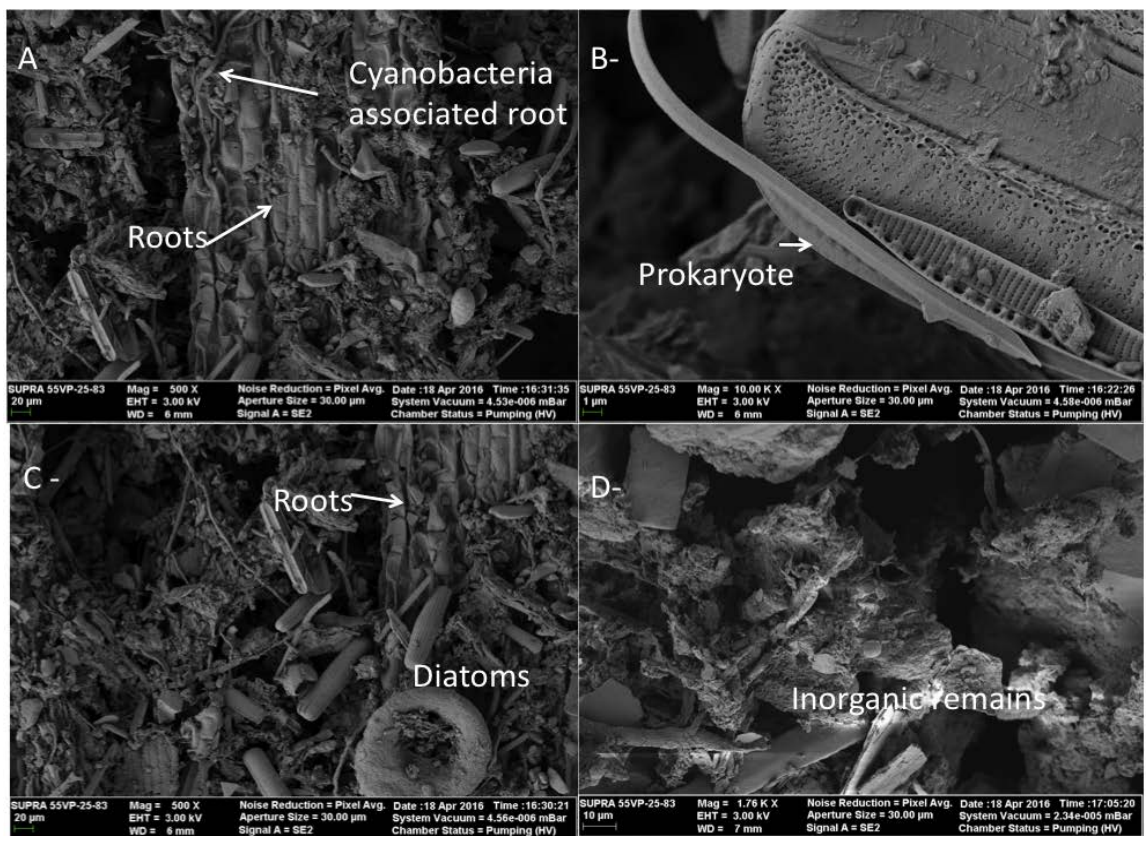

Figure 3. SEM image (A) (B) (C) active and (D) dead peatland.

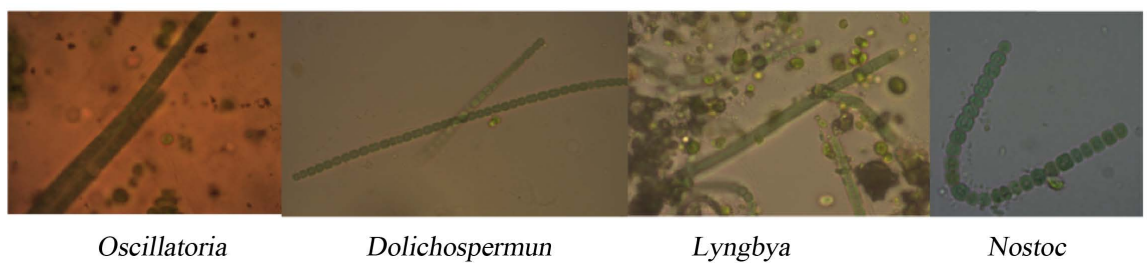

(a)

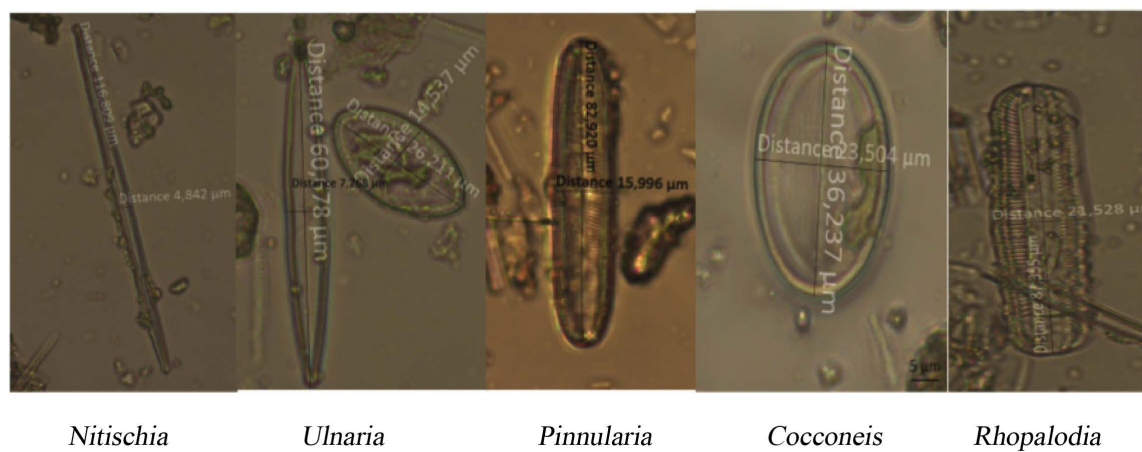

(b)

Figure 4. Diversity of cyanobacteria (a) and diatomea (b) from active peatland.

these environments, it can be proposed that the loss of water causes great changes in the physical-chemical characteristics of the soil, which leads to a modification of the microbiota.

As conclusion, the results showed that, in the dead peatland samples there was a decrease of Proteobacteria mainly Alpha and Gamma, moreover an increase of Acidobacterias and Gematimoidetes in approximately 5\% was observed. On the other hand Actinobacteria phyla increased markedly in dead peatland samples. 
Evidently is more resistant to the extreme conditions. The microbial response to desiccation would reflect adaptation strategies. The recovery of these lands should not only consist on the hydration of the soils but also in the bioinoculation of the native organisms. In that way, proteobacteria isolated from healthy soils would be the main candidates to develop a bioinoculation starter.

Ongoing research is developing inoculums with microorganisms isolated from "healthy soils" in order to produce a biofertilizer for the recovery of peatland dried by miner activities in Andean Altiplane.

\section{Acknowledgements}

The authors acknowledge the generous financial support by the PICT V Bicentenario 20101788 Project (FONCyT, Argentina). Authors are researchers from the National Research Council (CONICET) in Argentina and from the National Universities of Tucumán. This work was performed in the context of Proyecto "Análisis de Adaptación al Cambio Climático en Humedales Andinos". ID: 6188775-8-LP13. Ministerio del Medio Ambiente, Región de Antofagasta (http://portal.mma.gob.cl/).

\section{References}

[1] Hartley, A.J., Chong, G., Houston, J. and Mather, A.E. (2005) 150 Million Years of Climatic Stability: Evidence from the Atacama Desert, Northern Chile. The Geological Society, 162, 421-424. https://doi.org/10.1144/0016-764904-071

[2] Clarke, J.D.A. (2006) Antiquity of Aridity in the Chilean Atacama Desert. Geomorphology, 73,101-114. https://doi.org/10.1016/j.geomorph.2005.06.008

[3] Risacher, F., Alonso, H. and Salazar, C. (2003) The Origin of Brines and Salts in Chilean salars: A Hydrochemical Review. Earth-Science Reviews, 63, 249-293. https://doi.org/10.1016/S0012-8252(03)00037-0

[4] Stoertz, G.E. and Ericksen, G.E. (1974) Geology of Salars in Northern Chile. US Geological Survey Professional Paper, Washington, DC.

[5] Farías, M.E., Contreras, M., Rasuk, M.C., Kurth, D., Flores, M.R., Poiré, D.G., Novoa, F. and Visscher, P.T. (2014) Characterization of Bacterial Diversity Associated with Microbial Mats, Gypsum Evaporites and Carbonate Microbialites in Thalassic Wetlands: Tebenquiche and La Brava, Salar de Atacama Chile. Extremophiles, 18, 311-329. https://doi.org/10.1007/s00792-013-0617-6

[6] Stivaletta, N., Barbieri, R., Cevenini, F. and López-García, P. (2011) Physicochemical Conditions and Microbial Diversity Associated with the Evaporite Deposits in the Laguna de la Piedra (Salar de Atacama, Chile). Geomicrobiology Journal, 28, 83-95. https://doi.org/10.1080/01490451003653102

[7] Calvo, M.A.A., Pozo Torres, V.L., Rojas García, M.F. and Zenteno, A. (2000) Protección de humedales (Vegas y Bofedales) en el Norte de Chile http://aprchile.cl/pdfs/Trabajo\%20humedales\%20altoandinos_maac2.pdf

[8] http://www.conaf.cl/humedales-chilenos-altoandinos-ecosistemas-estrategicos-de-i mportancia-internacional/

[9] Ciren: centro de información de recursos naturales (2010) Caracterización base de vegas y bofedales altoandinos para una gestión sostenible de los recursos hídricos. 
Región de Antofagasta, Primera parte.

[10] Holden, J., Chapman, P.J. and Labadz, J.C. (2004) Artificial Drainage of Peatland: Hydrological and Hydrochemical Process and Wetland Restoration. Progress in Physical Geography, 28, 95-123. https://doi.org/10.1191/0309133304pp403ra

[11] Bardgett, R.D. and Shine, A. (1999) Linkages between Plant Litter Diversity, Soil Microbial Biomass and Ecosystem Function in Temperate Grasslands. Soil Biology and Biochemistry, 31, 317-321. https://doi.org/10.1016/S0038-0717(98)00121-7

[12] Vila, I. (2002) Sistemas intertropicales de altura: Humedales altiplánicos. In: Fernández Cirelli, A. and Abraham, Eds., El agua en Iberoamérica; de la escasez a la desertificación, Buenos Aires: CYTED XVII, CETA, Facultad de Ciencias Veterinarias, Universidad de Buenos Aires, 63-72.

[13] Gutknecht, J.L.M., Goodman, R.M. and Balser, T.C. (2006) Linking Soil Process and Microbial Ecology in Freshwater Wetland Ecosystems. Plant and Soil, 289, 17-34. https://doi.org/10.1007/s11104-006-9105-4

[14] Mentzer, J.L., Goodman, R. and Balser, T.C. (2006) Microbial Seasonal Response to Hydrologic and Fertilization Treatments in a Simulated Wet Prairie. Plant and Soil, 284, 85-100. https://doi.org/10.1007/s11104-006-0032-1

[15] Reyes, I., Valery, A. and Valduz, Z. (2006) Phosphate-Solubilizing Microorganisms Isolated from Rhizospheric and Bulk Soils of Colonizer Plants at an Abandoned Rock Phosphate Mine. Pant and Soil, 287, 69-75.

https://doi.org/10.1007/s11104-006-9061-Z

[16] Torsvik and Øvreas (2002) Microbial Diversity and Function in Soil: From Genes to Ecosystems. Current Opinion in Microbiology, 5, 240-245. https://doi.org/10.1016/S1369-5274(02)00324-7

[17] Van den Heuvel, R.N., van der Biezen, E., Jetten, M.S., Hefting, M.M. and Kartal, B. (2010) Denitrification at $\mathrm{pH} 4$ by a Soil-Derived Rhodanobacter-Dominated Community. Environmental Microbiology, 12, 3264-3271. https://doi.org/10.1111/j.1462-2920.2010.02301.x

[18] Siljanen, H.M.P., Saari, A., Bodrossy, L. and Martikainen, P.J. (2012) Seasonal Variation in the Function and Diversity of Methanotrophs in the Littoral Wetland of a Boreal Eutrophic Lake. FEMS Microbiology Ecology, 80, 548-555. https://doi.org/10.1111/j.1574-6941.2012.01321.x

[19] Messerli, B., Grosjean, M., Bonani, G., Burgi, A., Geyh, M.A., Graf, K., Ramseyer, K., Romero, H., Schotterer, U., Schreuer, H. and Vuille, M. (1993) Climate Change and Natural Resource Dynamics of the Atacama Altiplano during the Last 18,000 Years: A Preliminary Synthesis. Mountain Research and Development, 13, 117-127. https://doi.org/10.2307/3673629

[20] Departamento de Estudios y Planificación Dirección General de Aguas (2004) Actualización delimitación de acuiferos que alimentan vegas y bofedales, región de Antofagasta.

http://www.conaf.cl/humedales-chilenos-altoandinos-ecosistemas-estrategicos-de-i mportancia-internacional/

[21] Squeo, F.A., Warner, B.G., Aravena, R. and Espinoza, D. (2006) Bofedales: High Altitud Peatlands of the Central Andes. Revista Chilena de Historia Natural, 79, 245-255. https://doi.org/10.4067/S0716-078X2006000200010

[22] Dorador, C., Castillo, G., Witzel, K.P. and Vila, I. (2007) Bacterial Diversity in the Sediments of a Temperate Artificial Lake, Rapel Reservoir. Revista Chilena de Historia Natural, 80, 213-224. https://doi.org/10.4067/S0716-078X2007000200007 
[23] Hartman, W.H., Richardson, C.J., Vilgalys, R. and Bruland, G.L. (2008) Environmental and Anthropogenic Controls over Bacterial Communities in Wetland Soils. Proceedings of the National Academy of Sciences, 105, 17842-17847. https://doi.org/10.1073/pnas.0808254105

[24] Stanier, R.Y., Kunisawa, R., Mandel, M. and Cohen-Bazire, G. (1971) Purification and Properties of Unicellular Blue-Green Algae (Order Chroococcales). Bacteriological Reviews, 35, 171-205.

[25] van den Hoek, C., Mann, D.G. and Jahns, H.M. (1995) Algae. An Introduction to Phycology. Cambridge University Press, Cambridge.

[26] Schoenholtz, S.H., Van Miegroet, H. and Burger, J.A. (2000) A Review of Chemical and Physical Properties as Indicators of Forest Soil Quality: Challenges and Opportunities. Forest Ecology and Management, 138, 335-356. https://doi.org/10.1016/S0378-1127(00)00423-0

[27] Sylvia, D., Fuhrmann, J., Hartel, P. and Zuberer, D. (2005) Principles and Applications of Soil Microbiology. 2nd Edition, Pearson/Prentice Hall, Upper Saddle River, 640.

[28] McCauley, A., Jones, C. and Olson-Rutz, K. (2017) Soil pH and Organic Matter. Nutrient Management Module No. 8. http://landresources.montana.edu/nm/documents/NM8.pdf

[29] Rodriguez-Navarro (2000) Potassium Transport in Fungi and Plants. Biochimica et Biophysica Acta, 1469, 1-30.

[30] William, J.M. and Gosselink, J.G. (2015) Wetlands. 5th Edition, EEUU.

[31] Horneck, D.A., Sullivan, D.M., Owen, J.S. and Hart, J.M. (2011) Soil Test Interpretation Guide. EC1478, Oregon State University Extension Service, Corvallis.

[32] Aerts, R., Wallen, B. and Malmer, N. (1992) Growth-Limiting Nutrients in Sphagnum-Dominated Bogs Subject to Low and High Atmospheric Nitrogen Supply. Journal of Ecology, 80, 131-140. https://doi.org/10.2307/2261070

[33] Berendse, F., van Breemen, N. and Rydin, H. (2001) Raised Atmospheric $\mathrm{CO}_{2}$ Levels and Increased N Deposition Cause Shifts in Plant Species Composition and Production. Global Change Biology, 7, 591-598. https://doi.org/10.1046/j.1365-2486.2001.00433.x

[34] Hemond, H.F. (1983) The Nitrogen Budget of Thoreau's Bog. Ecology, 64, 99-109. https://doi.org/10.2307/1937333

[35] Urban, N.R. and Eisenreich, S.J. (1988) Nitrogen Cycling in a Forested Minnesota Bog. Canadian Journal of Botany, 66, 435-449. https://doi.org/10.1139/b88-069

[36] Gauci, V., Dise, N. and Fowler, D. (2002) Controls on Suppression of Methane Flux from a Peat Bog Subjected to Simulated Acid Rain Sulfate Deposition. Global Biogeochemical Cycles, 16, 1-12. https://doi.org/10.1029/2000GB001370

[37] Gauci, V., Matthews, E., Dice, N., Walter, B., Koch, D., Granberg, G. and Vile, M. (2004) Sulfur Pollution Suppression of the Wetland Methane Source in $20^{\text {th }}$ and $21^{\text {st }}$ Centuries. PNAS, 101, 12583-12587.

[38] Blodau, C. and Moore, T.R. (2003) Micro-Scale $\mathrm{CO}_{2}$ and $\mathrm{CH}_{4}$ Dynamics in a Peat Soil during a Water Table Fluctuation and Sulfate Pulse. Soil Biology and Biochemistry, 35, 535-547. https://doi.org/10.1016/S0038-0717(03)00008-7

[39] Vile, M.A., Bridgham, S.D. and Wieder, R.K. (2003) Atmospheric Sulfur Deposition Alters Pathways of Gaseous Carbon Production in Peatlands. Global Biogeochemical Cycles, 17, 1058. https://doi.org/10.1029/2002GB001966 
[40] Wieder, R.K. and Lang, G.E. (1986) Fe, Al, Mn, and S Chemistry of Sphagnum Peat in Four Peatlands with Different Metal and Sulfur Input. Water, Air and Soil Pollution, 29, 309-320. https://doi.org/10.1007/BF00158762

[41] Moore, T., Blodau, C., Turunen, J., Reulet, N. and Richard, P.J.H. (2004) Patterns of Nitrogen and Sulfur Accumulation and Retention in Ombrotrophic Bogs, Eastern Canada. Global Change Biology, 11, 356-367. https://doi.org/10.1111/j.1365-2486.2004.00882.x

[42] Urban, N.R., Eisenreich, S.J. and Grigal, D.F. (1989) Sulfur Cycling in a Forested Sphagnum Bog in Northern Minnesota. Biogeochemistry, 7, 81-109. https://doi.org/10.1007/BF00004123

[43] Novák, M., Wieder, R.K. and Schell, W.R. (1994) Sulfur during Early Diagenesis in Sphagnum Peat: Insights from d34S Ratio Profiles in 210Pb-Dated Peat Cores. Limnology and Oceanography, 39, 1172-1185. https://doi.org/10.4319/lo.1994.39.5.1172

[44] Turetsky, M., Wieder, R.K. and Williams, C.J. (2000) Organic Matter Accumulation, Peat Chemistry, and Permafrost Melting in Peatlands of Boreal Alberta. Ecoscience, 7, 379-392. https://doi.org/10.1080/11956860.2000.11682608

[45] Kloepper, J. and Beuchamp, C. (1992) A Review of Issues Related to Measuring Colonization of Plant Roots by Bacteria. Canadian Journal of Microbiology, 38, 1219-1232. https://doi.org/10.1139/m92-202

[46] Chao, W.L., Nelson, E.B., Harman, G.E. and Hoch, H.C. (1986) Colonization of the Rhizosphere by Biological Control Agents Applied to Seeds. Phytopathology, 76, 60-65. https://doi.org/10.1094/Phyto-76-60

[47] Zhou, X., Fornara, D., Ikenaga, M., Akagi, I., Zhang, R. and Jia, Z. (2016) The Resilience of Microbial Community under Drying and Rewetting Cycles of Three Forest Soils. Frontiers in Microbiology, 19, 1101.

[48] Pankratov, T.A. (2012) Acidobacteria in Microbial Communities of the Bog and Tundra Lichens. Microbiology, 81, 51-58. https://doi.org/10.1134/S0026261711060166

[49] Wang, Z. Crawford, D.L., Pometto, A.L. and Rafii (1989) Survival and Effect of Wildtype, Mutant, and Recombinat Streptomyces in Soil Ecosystem. Canadian Journal of Microbiology, 35, 535-543.

[50] Mason, M.G., Ball, A.S., Reeder, B.J., Silkstone, G., Nicholls, P. and Wilson, M.T. (2001) Extracellular Heme Peroxidases in Actinomycetes: A Case of Mistaken Identity. Applied and Environmental Microbiology, 67, 4512-4519.

[51] McCarthy, A.J. and Williams, S.T. (1992) Actinomycetes as Agents of Biodegradation in the Environment-A Review. Gene, 115, 189-192.

[52] Kieser, T., Bibb, M.J., Buttner, M.J., Chater, K.F. and Hopwood, D.A. (2000) Practical Streptomyces Genetics. John Innes Foundation, Norwich.

[53] Goodfellow, M. and Williams, S. (1983) Ecology of Actinomycetes. Annual Review of Microbiology, 37, 189-216. https://doi.org/10.1146/annurev.mi.37.100183.001201

[54] Chowdhury, S.P., Schmid, M., Hartmann, A. and Tripathi, A.K. (2009) Diversity of 16S-rRNA and nifH Genes Derived from Rhizosphere Soil and Roots of an Endemic Drought Tolerant Grass, Lasiurus sindicus. European Journal of Soil Biology, 45, 114-122. https://doi.org/10.1016/j.ejsobi.2008.06.005

[55] Barnard, R.L., Osborne, C.A. and Firestone, M.K. (2013) Responses of Soil Bacterial and Fungal Communities to Extreme Desiccation and Rewetting. The ISME Journal, 7, 2229-2241. https://doi.org/10.1038/ismej.2013.104 
[56] Niederberger, T.D., Sohm, J.A., Gunderson, T.E., Parker, A.E., Tirindelli, J., Capone, D.G., Carpenter, E.J. and Cary, S.C. (2015) Microbial Community Composition of Transiently Wetted Antartic Dry Valley Soils. Frontiers in Microbiology, 6, 1-12. https://doi.org/10.3389/fmicb.2015.00009

[57] Hugenholtz, P., Goebel, B.M. and Pace, N.D. (1998) Impact of Culture-Independent Studies on the Emerging Phylogenetic View of Bacterial Diversity. Journal of Bacteriology, 180, 4765-4774.

[58] Janssen, P.H. (2006) Identifying the Dominant Soil Bacterial Taxa in Libraries of 16S rRNA and 16S rRNA Genes. Applied and Environmental Microbiology, 72, 1719-1728. https://doi.org/10.1128/AEM.72.3.1719-1728.2006

[59] Tringe, S.G., von Mering, C., Kobayashi, C., Salamov, A.A., Chen, K., Chang, H.W., Podar, M., Short, J.M., Mathur, E.J., Detter, J.C., Bork, P., Hugenholtz, P. and Rubin, E.M. (2005) Comparative Metagenomics of Microbial Communities. Science, 308, 554-557. https://doi.org/10.1126/science.1107851

[60] Barns, S.M., Takala, S.L. and Kuske, C.R. (1999) Wide Distribution and Diversity of Members of the Bacterial Kingdom Acidobacterium in the Environment. Applied and Environmental Microbiology, 65, 1731-1737.

[61] Stark, J.M. and Firestone, M.K. (1995) Mechanisms for Soil Moisture Effects on Activity of Nitrifying Bacteria. Applied and Environmental Microbiology, 61, 218-221.

[62] Potts, M. (1994) Desiccation Tolerance in Prokaryotes. Microbiological Reviews, 58, 755-805.

[63] Griffin, D.M. (1977) Water Potential and Wood-Decay Fungi. Annual Review of Phytopathology, 15, 319-329. https://doi.org/10.1146/annurev.py.15.090177.001535

[64] DeBruyn, J., Nixon, L.T., Fawaz, M., Johnson, A.M. and Radosevich, M. (2011) Global Biogeography and Quantitative Seasonal Dynamics of Gemmatimonadetes in Soil. Applied and Environmental Microbiology, 77, 6295-6300.

[65] Thomas, F., Hehemann, J.H., Rebuffet, E., Czjzek, M. and Michel, G. (2011) Environmental and Gut Bacteroidetes: The Food Connection. Frontiers in Microbiology, 2, 1-16.

[66] Stanish, L., Sean, P., O’Neill, A., Gonzalez, T.M., Legg, J.K., McKnight, D. and Spaulding, S. (2013) Bacteria and Diatom Co-Occurrence Patterns in Microbial Mats from Polar Desert Streams. Environmental Microbiology, 15, 1115-1131. https://doi.org/10.1111/j.1462-2920.2012.02872.x

[67] Yamada, T. and Sekiguchi, Y. (2009) Cultivation of Uncultured Chloroflexi Subphyla: Significance and Ecophysiology of Formerly Uncultured Chloroflexi "Subphylum I" with Natural and Biotechnological Relevance. Microbes and Environments, 24, 205-216. https://doi.org/10.1264/jsme2.ME09151S

[68] Davis, K.E.R., Sangwan, P. and Janssen, P.H. (2011) Acidobacteria, Rubro-Bacteridae and Chloroflexi Are Abundant among Very Slow-Growing and Mini-Colony-Forming Soil Bacteria. Environmental Microbiology, 13, 798-805. https://doi.org/10.1111/j.1462-2920.2010.02384.x

[69] Schimel, J., Balser, T.C. and Wallenstein, M. (2007) Microbial Stress Response Physiology and Its Implications for Ecosystem Function. Ecology, 88, 1386-1394. https://doi.org/10.1890/06-0219

[70] Lv, X., Yu, J., Fu, Y., Ma, B., Qu, F., Ning, K. and Wu, H. (2014) A Meta-Analysis of the Bacterial and Archeal Diversity Observed in Wetland Soils. The Scientific World Journal, 2014, Article ID: 437684.

[71] Lin, W. and Pan, Y. (2014) Aputtive Greigite-Type Magnetosome Gene Cluster 
from the Candidate Phylum Latescibacteria. Environmental Microbiology Reports, 7, 237-242. https://doi.org/10.1111/1758-2229.12234

[72] Whitton, B.A. (2000) Soils and Rice-Fields. In: Whitton, B.A. and Potts, M., Eds., The Ecology of Cyanobacteria, The Diversity in Time and Space, Kluwer Academic Publishers, Dordrecht, 233-255.

[73] Lange, O.L., Bilger, W., Rimke, S. and Schreiber, U. (1989) Chlorophyll Fluorescence of Lichens Containing Green and Blue-Green Algae during Hydration by Water Vapor Uptake and by Addition of Liquid Water. Botanica Acta, 102, 306-313. https://doi.org/10.1111/j.1438-8677.1989.tb00110.x

[74] Potts, M. (2001) Desiccation Tolerance: A Simple Process? Trends in Microbiology, 9, 553-559.

[75] Kranner, I., Zorn, M., Turk, B., Wornik, S., Beckett, R.P. and Batic, F. (2003) Biochemical Traits of Lichens Differing in Relative Desiccation Tolerance. New Phytologist, 160, 167-176. https://doi.org/10.1046/j.1469-8137.2003.00852.x

[76] Kranner, I., Beckett, R., Hochman, A. and Nash, T.H. III (2008) Desiccation-Tolerance in Lichens: A Review. Bryologist, 111, 576-593.

https://doi.org/10.1639/0007-2745-111.4.576

[77] Potts, M., Slaughter, S.M., Hunneke, F.U., Garst, J.F. and Helm, R.F. (2005) Desiccation Tolerance of Prokaryotes: Application of Principles to Human Cells. Integrative and Comparative Biology, 45, 800-809. https://doi.org/10.1093/icb/45.5.800

[78] Farias, M.E., Rascovan, N., Toneatti, D.M., Albarracín, V.H., Flores, M.R. and Poiré, D.G. (2013) The Discovery of Stromatolites Developing at $3570 \mathrm{~m}$ above Sea Level in a High-Altitude Volcanic Lake Socompa, Argentinean Andes. PLoS ONE, 8, e53497. https://doi.org/10.1371/journal.pone.0053497

[79] Rasuck, M.C., Kurth, D., Flores, M.R., Contreras, M., Novoa, F., Poire, D. and Farias, M.E. (2014) Microbial Characterization of Microbial Ecosystems Associated to Evaporites Domes of Gypsum in Salar de Llamara in Atacama Desert. Microbial Ecology, 68, 483-494. https://doi.org/10.1007/s00248-014-0431-4

[80] Rasuk, M.C., Fernández, A.B., Kurth, D., Contreras, M., Novoa, F., Poiré, D. and Farias, M.E. (2016) Bacterial Diversity in Microbial Mats and Sediments from the Atacama Desert. Microbial Ecology, 71, 44-56. https://doi.org/10.1007/s00248-015-0649-9

[81] Fernandez, A.B., Rasuck, M.C., Visscher, P., Contreras, M., Novoa, F., Poire, D., Patterson, M.M., Ventosa, A. and Farias, M.E. (2016) Microbial Diversity in Sediment Ecosystems (Evaporites Domes, Microbial Mats, and Crusts) of Hypersaline Laguna Tebenquiche. Frontiers in Microbiology, 7, 1284.

[82] Pointing, S.B., Chan, Y., Lacap, D.C., Lau, M.C.Y., Jurgens, J.A. and Farrell, R.L. (2009) Highly Specialized Microbial Diversity in Hyper-Arid Polar Desert. Proceedings of the National Academy of Sciences, 106, 19964-19969.

[83] Niederberger, T.D., McDonald, I.R., Hacker, A.L., Soo, R.M., Barrett, J.E. and Wall, D.H. (2008) Microbial Community Composition in Soils of Northern Victoria Land, Antarctica. Environmental Microbiology, 10, 1713-1724. https://doi.org/10.1111/j.1462-2920.2008.01593.x

[84] Niederberger, T.D., Sohm, J.A., Tirindelli, J., Gunderson, T., Capone, D.G. and Carpenter, E. (2012) Diverse and Highly Active Diazotrophic Assemblages Inhabit Ephermally Wetted Soils of the Antarctic Dry Valleys. FEMS Microbiology Ecology, 82, 376-390. https://doi.org/10.1111/j.1574-6941.2012.01390.x

[85] Smith, J.L., Barrett, J., Tusnády, G., Rejto, L. and Cary, S.C. (2010) Resolving Envi- 
ronmental Drivers of Microbial Diversity in Antarctic Soils. Antarctic Science, 22, 673-680. https://doi.org/10.1017/S0954102010000763

[86] Lee, C.K., Barbier, B.A., Bottos, E.M., McDonald, I.R. and Cary, S.C. (2012) The Inter-Valley Soil Comparative Survey: The Ecology of Dry Valley Edaphic Microbial Communities. The ISME Journal, 6, 1046-1057. https://doi.org/10.1038/ismej.2011.170

[87] Pouličková, A.P., Hajoková, P., Krenkivá, P. and Hájek, M. (2004) Distribution of Diatoms and Bryophytes on the Linear Transects through Spring Fens. Nova Hedwigia, 78, 411-424. https://doi.org/10.1127/0029-5035/2004/0078-0411

[88] Solak, C.N. and Ács, É. (2011) Water Qualıty Monitorıng in European and Turkısh Rivers using Diatoms. Turkish Journal of Fisheries and Aquatic Sciences, 11, 329-337. https://doi.org/10.4194/trjfas.2011.0105

[89] Hilton, J. (2014) Ecology and Evolution of Diatom-Associated Cyanobacteria through Genetic Analyses. UC Santa Cruz Electronic Theses and Dissertations. http://escholarship.org/uc/item/4p80f49c\#page-1 